\title{
Tissue culture and genetic transformation of cabbage (Brassica oleracea var. capitata): an overview
}

\author{
Aneta Gerszberg ${ }^{1}$
}

Received: 21 June 2018 / Accepted: 21 July 2018 / Published online: 31 July 2018

(c) The Author(s) 2018

\begin{abstract}
Main conclusion The main goal of this publication is an overview of the biotechnological achievements concerning in vitro cultures and transformation of Brassica oleracea var. capitata.
\end{abstract}

Faced with the requirements of the global food market, intensified work on the genetic transformation of economically important plants is carried out in laboratories around the world. The development of efficient procedures for their regeneration and transformation could be a good solution for obtaining, in a shorter time than by traditional methods, plants with desirable traits. Furthermore, conventional breeding methods are insufficient for crop genetic improvement not only because of being time-consuming but also because they are severely limited by sexual incompatibility barriers. This problem has been overcome by genetic engineering, which seems to be a very good technique for cabbage improvement. Despite the huge progress that has been made in the field of plant regeneration and transformation methods, up to now, no routine transformation procedure has been developed in the case of cabbage. This problem stems from the fact that the efficiency of cabbage transformation is closely related to the genotype and some varieties are recalcitrant to transformation. It is obvious that it is not possible to establish one universal regeneration and transformation protocol for all varieties of cabbage. Therefore, it seems fully justified to develop the above-mentioned procedures for individual economically important cultivars. Despite the obstacles of cabbage transformation in laboratories of many countries, especially those where this vegetable is extremely popular (e.g., China, India, Korea, Malaysia, Pakistan), such attempts are made. This article reviews the achievements in the field of tissue culture and cabbage transformation from the last two decades.

Keywords Brassica oleracea var. capitata $\cdot$ Cabbage $\cdot$ Tissue culture $\cdot$ Genetic transformation

\section{Introduction}

Among large genus of Brassica, six species (Brassica rapa, B. nigra, B. oleracea, B. carinata, B. juncea, B. napus) are widely used worldwide as forage, oil seeds, condiments or vegetable crops. Three of them (B. nigra, B. rapa and $B$. oleracea) are diploid, while the other three are allotetraploids (Fig. 1). The extensive research confirmed their mutual genetic relationships (Liu et al. 2014).

Aneta Gerszberg

aneta.gerszberg@biol.uni.lodz.pl

1 Department of Genetics, Plant Molecular Biology and Biotechnology, Faculty of Biology and Environmental Protection, University of Lodz, Banacha 12/16, 90-237 Lodz, Poland
One of the most important components of the human diet alongside fruits is vegetables. Among vegetables, one of the most important groups, due to their nutritional value, are those belonging to the Brassicaceae family $(2 n=18)$ (Fig. 1). It is a multifarious group that includes crops such as cauliflower, cabbage, Savoy cabbage, collards, Brussels sprouts, broccoli, turnip, rutabaga, kale and kohlrabi (Ravanfar et al. 2017). Brassica oleracea var. capitata (common name: cabbage) is an extremely valuable source of folic acid, vitamins (e.g., C, K, A), flavonoids and calcium (Gerszberg et al. 2015). Moreover, cabbage comprises secondary metabolites (glucosinolates) and amino acids that contribute to its anti-inflammatory and anticancer properties (Hafidh et al. 2013; Zielińska et al. 2015). The largest producers of cabbage in the world are China, India and Pakistan, while Poland ranks among the top ten (FAOSTAT 2016). The biotic and abiotic stresses as well as pests have a significant impact on the loss of both quality 


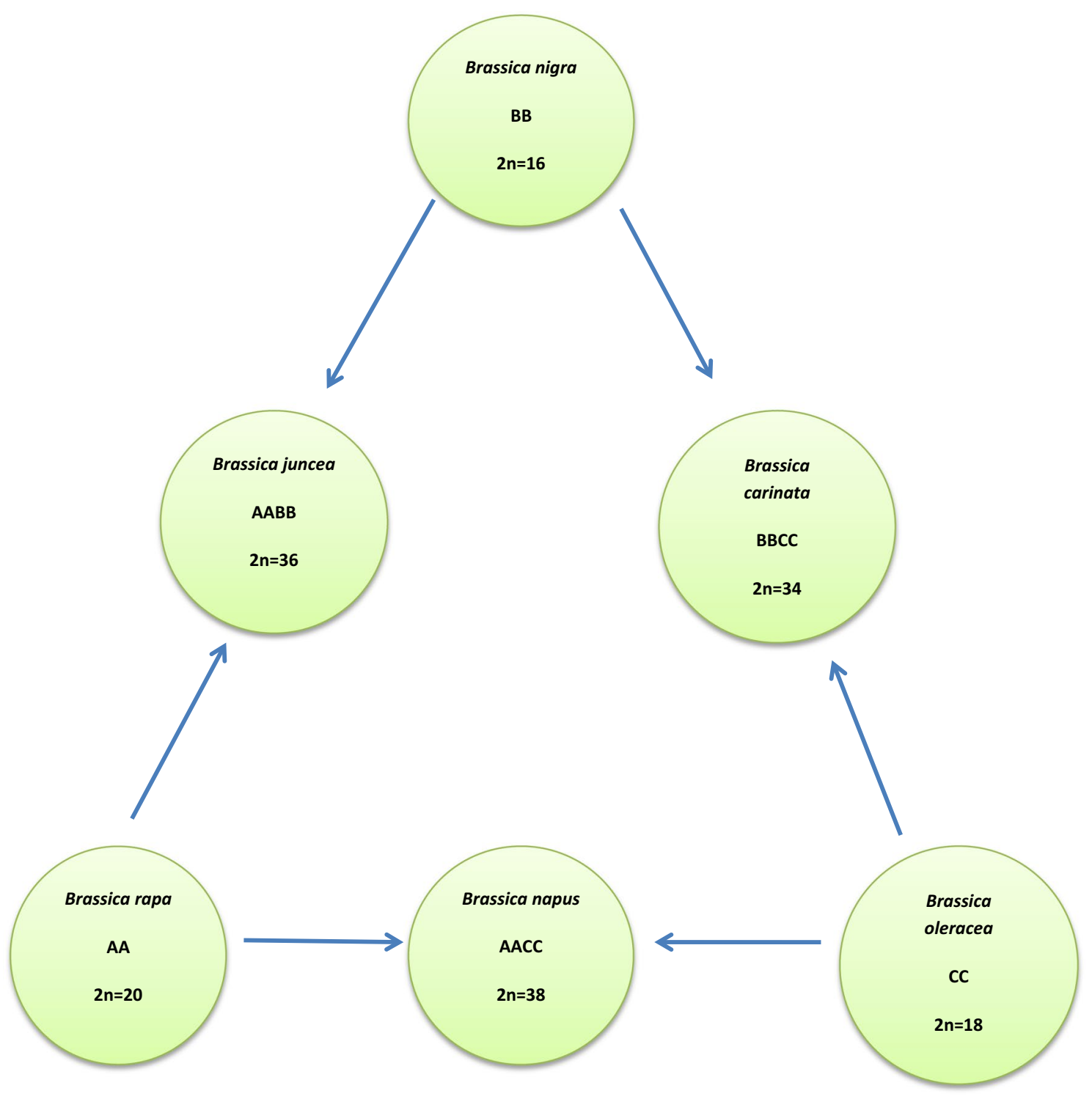

Fig. 1 Relationships between members of the plant genus of Brassica (the U triangle) (based on Liu et al. 2014)

and quantity of cabbage yield (Yi et al. 2013). Mostly, severe damages are caused by fungal diseases caused by Alternaria brassicicola, Botrytis cinerea, Pythium spp. Plasmodiophora brassicae as well as by lepidopteran insects (Plutella xylostella) (Yi et al. 2013; Gerszberg et al. 2015). To overcome this problem, many studies have been carried out to optimize the regeneration (Gerszberg et al. 2015; Daud et al. 2015; Gambhir et al. 2017a, b) and transformation procedures of B. oleracea var. capitata (Yi et al. 2013; Hur and Min 2015; Ravanfar et al. 2017) (Table 1). Since conventional breeding techniques are inadequate, it seems that the genetic transformation of cabbage appears to be an important method for improving this vegetable. The advancement of genetic engineering can overcome the barriers associated with the sexual incompatibility of Brassica oleracea cultivars, resulting in hybrids with new desirable agronomic traits. It is worth noting that many articles refer to the genetic modification of rape or cauliflower, while relatively few publications focus strictly on the transformation of cabbage. Therefore, the objective of this article is to summarize the achievements in the field of regeneration and genetic transformation of cabbage.

\section{Tissue culture of Brassica oleracea var. capitata}

Establishment of an efficient regeneration protocol is a prerequisite step for transferring genes into plants. Plant tissue culture research in cabbage was reported by different scientists exploiting various explants such as mesophyll protoplast 
Table 1 Examples of successful B. oleracea var. capitata regeneration

\begin{tabular}{|c|c|c|c|c|}
\hline Cultivar & Type of explants & The best variant of medium & $\%$ of shoot regeneration & References \\
\hline Baochun F1 & $\begin{array}{l}\text { Mesophyll protoplast } \\
\text { culture }\end{array}$ & $\begin{array}{l}\mathrm{MS}+3 \mathrm{mg} / \mathrm{L} \\
\mathrm{kin}+0.1 \mathrm{mg} / \mathrm{L} \mathrm{GA} 3\end{array}$ & $\begin{array}{l}100 \% \text { callus produced } \\
\text { shoots }\end{array}$ & Fu et al. (1985) \\
\hline Varaždinsko, Hawke F2 & Microspore culture & $\begin{array}{l}\mathrm{NLN}+5 \mathrm{mg} / \mathrm{L} \mathrm{ABA}- \\
\text { germination embryos } \\
\text { B } 5+2 \% \text { sucrose }\end{array}$ & $54.7-70.6 \%$ & Rudolf et al. (1999) \\
\hline $\begin{array}{l}\text { Zigan No.1, Hongmu, } \\
\text { Ruby ball }\end{array}$ & Protoplast culture & $\begin{array}{l}\text { In first stage of protoplast } \\
\text { culture, it is important to } \\
\text { add nurse cell of tuber } \\
\text { mustard. MS }+1 \mathrm{mg} / \mathrm{L} \\
\text { BA }+0.2 \mathrm{mg} / \mathrm{L} \mathrm{NAA}- \\
\text { regeneration of plantlets }\end{array}$ & $\begin{array}{l}33 \% \text { Zigan No.1 } \\
47 \% \text { Hongmu } \\
56 \% \text { Ruby ball }\end{array}$ & Chen et al. (2004) \\
\hline $\begin{array}{l}\text { Křimické } \\
\text { Holt } \\
\text { Landrace Zakamenné } \\
\text { Landrace } \\
\text { Zázrivá } \\
\text { Landrace Lutiše } \\
\text { Trvanlivé D } \\
\text { Vysocké } \\
\text { Kalibos }\end{array}$ & Cotyledonary embryos & MS $+1 \%$ sucrose $+1 \%$ agar & $\begin{array}{l}18.18 \text { and } 16.6 \% \\
5.88 \text { and } 11.11 \% \\
23.53 \text { and } 39.34 \% \\
44.83 \text { and } 52.00 \% \\
21.74 \% \\
42.86 \% \\
25.93 \% \\
71.79 \%\end{array}$ & Klima et al. (2004) \\
\hline $\begin{array}{l}\text { Kamienna głowa } \\
\text { Sława of Einkhunzen }\end{array}$ & Anther culture & $\begin{array}{l}\text { B5 + } 20 \mathrm{mg} / \mathrm{L} \mathrm{Kin}+2 \% \\
\text { sucrose }\end{array}$ & $\begin{array}{l}\text { Kamienna głowa } 17.1 \% \\
\text { Sława z Einkhunzen } 8.3 \%\end{array}$ & Krzyżanowska et al. (2006) \\
\hline N/A & Hypocotyl, cotyledon & $\begin{array}{l}\mathrm{MS}+2 \mathrm{mg} / \mathrm{L} \mathrm{BA}+0.1 \mathrm{mg} / \\
\text { LNAA }\end{array}$ & $\begin{array}{l}50 \% \text { (hypocotyls) } \\
40 \% \text { (cotyledons) }\end{array}$ & Munshi et al. (2007) \\
\hline Rubin & Cotyledon, hypocotyl, root & $\begin{array}{l}\mathrm{MS}+1.0 \mathrm{mg} / \mathrm{L}+0.1 \mathrm{mg} / \mathrm{L} \\
\mathrm{IBA} \text { Kin (cotyledon) } \\
\mathrm{MS}+1 \mathrm{mgL} / \mathrm{BA} \text { (hypoco- } \\
\text { tyl) } \\
\mathrm{MS}+1 \mathrm{mgL} / \mathrm{BA}+0.1 \mathrm{mg} / \mathrm{L} \\
\mathrm{IBA} \text { (root) }\end{array}$ & $\begin{array}{l}41 \% \text { (cotyledon) } \\
75 \% \text { (hypocotyl) } \\
14 \% \text { (root) }\end{array}$ & Pavlovic et al. (2010) \\
\hline DL 20, DM 56 & Microspore culture & $\begin{array}{c}\mathrm{MS}+8.9 \mathrm{BAP} \mu \mathrm{M} / \mathrm{L}+2.7 \\
\mathrm{NAA} \mu \mathrm{M} / \mathrm{L}+50 \mu \mathrm{M} / \mathrm{L}\end{array}$ & $\begin{array}{l}42.9 \% \text { (DL 20), } \\
40.1 \% \text { (DM 56) }\end{array}$ & Cristea et al. (2012) \\
\hline $\begin{array}{l}\text { Kamienna głowa, Amager, } \\
\text { Kilaxy F1, Benia F1, } \\
\text { Reball F1, Rodeo F1 }\end{array}$ & $\begin{array}{l}\text { Protoplasts from leaves and } \\
\text { hypocotyls }\end{array}$ & MS medium PGRs free & $\begin{array}{l}\text { Mean } 0.0-34.6 \% \\
29.8 \% \text { for leaves-derived } \\
\text { protoplasts } \\
26.2 \% \text { for hypocotyl- } \\
\text { derived protoplasts }\end{array}$ & $\begin{array}{l}\text { Kielkowska and Damaus } \\
\text { (2012) }\end{array}$ \\
\hline $\begin{array}{l}\mathrm{R} 1, \mathrm{R} 5, \mathrm{R} 7, \mathrm{R} 9, \mathrm{R} 33, \mathrm{~K} 1, \\
\mathrm{~K} 6, \mathrm{~K} 7, \mathrm{~K} 23, \mathrm{~K} 29, \mathrm{~K} 35, \\
\mathrm{~K} 48, \mathrm{~K} 50, \mathrm{~K} 75\end{array}$ & Lateral buds & $\begin{array}{l}\mathrm{MS}+2 \mathrm{mg} / \mathrm{L} \mathrm{BA}+1.0 \mathrm{IBA} \\
\mathrm{mg} / \mathrm{L}\end{array}$ & $80-100 \%$ & Pavlovic et al. (2012) \\
\hline $\begin{array}{l}\text { Cabeza Negra 2, Arena, } \\
\text { Red Amager }\end{array}$ & Cotyledon, hypocotyl, stem & $\begin{array}{l}\mathrm{MS}+2 \mathrm{mg} / \mathrm{L} \text { BAP }+0.2- \\
04 \text { mg/L IBA or NAA } \\
\text { (hypocotyl) }\end{array}$ & $\begin{array}{l}300 \text { shoots (Cabeza Negra } \\
2 \text { and Red Amager) } \\
\text { (hypocotyl) } \\
25 \text { shoots (Arena) }\end{array}$ & $\begin{array}{l}\text { Dănăilă-Guidea et al. } \\
\text { (2012) }\end{array}$ \\
\hline K7 & Zygotic embryos & $\begin{array}{l}\mathrm{MS}+1 \mathrm{mg} / \mathrm{L} \mathrm{BA} \text { or } \\
\mathrm{MS}+1 \mathrm{mg} / \mathrm{L} \mathrm{Kin}\end{array}$ & $56 \%$ & Pavlovic et al. (2013) \\
\hline Pride of India & Cotyledon, hypocotyl & $\begin{array}{l}\mathrm{MS}+1.5 \mathrm{mg} / \mathrm{L} \\
\mathrm{BAP}+0.5 \mathrm{mg} / \mathrm{L} \text { NAA } \\
(\text { cotyledon }) \\
\mathrm{MS}+2 \mathrm{mg} / \mathrm{L} \\
\mathrm{BAP}+0.25 \mathrm{mg} / \mathrm{L} \mathrm{IAA}\end{array}$ & $\begin{array}{l}\text { 5.334 shoots per explant } \\
\text { (cotyledon) } \\
\text { 6.0 shots per explant } \\
\text { (hypocotyl) }\end{array}$ & Sharma et al. (2014) \\
\hline KY cross & Cotyledon, hypocotyl & $\begin{array}{l}\mathrm{MS}+2.27 \mu \mathrm{M} \text { TDZ } \\
\quad \text { (hypocotyl) } \\
\mathrm{MS}+\end{array}$ & $\begin{array}{l}56.67 \% \text { (cotyledon) } \\
80 \% \text { (hypocotyl) }\end{array}$ & Ravanfar et al. (2014) \\
\hline Saint & Hypocotyl & $\begin{array}{c}\mathrm{MS}+\mathrm{BAP} 4 \mathrm{mg} / \mathrm{l}+\mathrm{IAA} \\
5 \mathrm{mg} / \mathrm{l}+\text { Zeatin } 4 \mathrm{mg} / \mathrm{l}\end{array}$ & $100 \%$ & Qamar et al. (2014) \\
\hline
\end{tabular}


Table 1 (continued)

\begin{tabular}{|c|c|c|c|c|}
\hline Cultivar & Type of explants & The best variant of medium & $\%$ of shoot regeneration & References \\
\hline $\begin{array}{l}\text { Kamienna głowa, Amager, } \\
\text { Sława of Einkhunzen, } \\
\text { Brunświcka, Ditmarska, } \\
\text { Zora, Ula, Replika }\end{array}$ & Cotyledon, hypocotyl & $\begin{array}{l}\mathrm{MS}+8.88 \mu \mathrm{M}(\mathrm{BAP} \\
\quad+0.53 \mu \mathrm{M} \text { NAA) }\end{array}$ & 22.2-66.6\% (hypocotyl) & Gerszberg et al. (2015) \\
\hline N/A & Stem, root, leaf, petiole & $\begin{array}{l}\mathrm{MS}+1.0 \mathrm{mg} / \mathrm{L} \\
\mathrm{NAA}+1.5 \mathrm{mg} / \mathrm{L} \text { BAP } \\
(\text { steam })\end{array}$ & $\begin{array}{l}93.18 \% \text { (stem) } \\
91.40 \% \text { (root) }\end{array}$ & Daud et al. (2015) \\
\hline $\begin{array}{l}\text { Zhonggan 11, Chunfeng, } \\
\text { Parel, Meiweizaosheng }\end{array}$ & Microspore culture & $\mathrm{NLN}+20 \mathrm{mg} / \mathrm{L}$ AsA & $\begin{array}{l}\text { Zhonggan } 11164.2 \text { (no.) } \\
\text { Chunfeng } 15.1 \\
\text { Parel 53.1 } \\
\text { Meiweizaosheng } 57.5\end{array}$ & Zeng et al. (2015) \\
\hline Pride of India & Leaf, petiole & $\begin{array}{l}\mathrm{MS}+0.22 \mathrm{mg} / \mathrm{L} \\
\mathrm{TDZ}+0.02 \mathrm{mg} / \mathrm{L} \text { NAA } \\
\text { (leaf) } \\
\mathrm{MS}+0.33 \mathrm{mg} / \mathrm{L} \\
\mathrm{TDZ}+0.02 \mathrm{mg} / \mathrm{L} \text { NAA } \\
\text { (petiole) }\end{array}$ & $\begin{array}{l}91.11 \% \text { (leaf) } \\
88.88 \% \text { (petiole) }\end{array}$ & $\begin{array}{l}\text { Gambhir and Srivastava } \\
\text { (2015) }\end{array}$ \\
\hline Ercis & Cotyledon, hypocotyl & $\begin{array}{l}\mathrm{MS}+2 \mathrm{mg} / \mathrm{L} \text { BAP } \\
\text { (hypocotyl) } \\
\mathrm{MS}+2 \mathrm{mg} / 1 \\
\mathrm{BAP}+0.1 \mathrm{mg} / \mathrm{l} \mathrm{NAA} \\
\text { and } \mathrm{MS}+0.5 \mathrm{mg} / \mathrm{BAP} \\
\text { (cotyledon) }\end{array}$ & $\begin{array}{l}100 \% \text { (hypocotyl) } \\
91.6 \% \text { (cotyledon) }\end{array}$ & Ertac and Tuncer (2016) \\
\hline Pride of India & Cotyledon, hypocotyl & $\begin{array}{l}\mathrm{MS}+0.330 \mathrm{mg} / \mathrm{l} \\
\mathrm{TDZ}+79.70 \mathrm{mg} / \mathrm{IAA} \\
\text { (cotyledon) } \\
\mathrm{MS}+0.220 \mathrm{mg} / \mathrm{l} \\
\mathrm{TDZ}+0.088 \mathrm{mg} / \mathrm{IAA} \\
\text { (hypocotyl) }\end{array}$ & $\begin{array}{l}91.11 \% \text { (cotyledon) } \\
94.4 \% \text { (hypocotyl) }\end{array}$ & Gambhir et al. (2017a) \\
\hline
\end{tabular}

N/A not available

culture (Fu et al. 1985; Chen et al. 2004), microspore cultures (Rudolf et al. 1999), cotyledons and hypocotyls (Klima et al. 2004; Munshi et al. 2007; Pavlovic et al. 2010; Ravanfar et al. 2014; Sharma et al. 2014; Gerszberg et al. 2015; Gambhir et al. 2017a), meristematic apex (Dănăilă-Guidea et al. 2012), roots (Pavlovic et al. 2010; Daud et al. 2015), lateral buds (Pavlovic et al. 2012), androgenic embryos (Krzyżanowska et al. 2006), immature zygotic embryos (Pavlovic et al. 2013), leaf and petiole (Gambhir and Srivastava 2015). Considering cabbage, many results pointed out that this crop regeneration and transformation efficiency greatly depended on the genotype (Gerszberg et al. 2015). Thus, it is fully justified to conduct studies on regeneration potential of different cultivars of B. oleracea var. capitata.

\section{Type of explants}

To develop the best regeneration protocol for cabbage, different factors such as the type of explant, its age, media supplemented with various plant growth regulators (PGRs) were examined. Recently, research was focused mainly on hypocotyl and cotyledon explants pointing to their huge potential for shoot organogenesis (Munshi et al. 2007;
Gerszberg et al. 2015; Gambhir et al. 2017a). Munshi et al. (2007) and Sharma et al. (2014) proved that cotyledon explants showed organogenesis superiority over hypocotyl ones. Nevertheless, a lot of studies reported that better regeneration effects were obtained using hypocotyl explants (Pavlovic et al. 2010; Ravanfar et al. 2014; Gerszberg et al. 2015). However, the subtypes of hypocotyl explants (parts of a hypocotyl section) have no effect on the regeneration of shoots (Gerszberg et al. 2015). Additionally, morphogenic response in hypocotyl explants occurred faster than the cotyledon ones (Ravanfar et al. 2014). Several studies compared quite different explants. For example, Daud et al. (2015) showed that the efficiency of shoot regeneration ability followed the order stem $>$ root $>$ petiole $>$ leaf. Generally in most species, including cabbage, not only the type of explant but also its age is important. Based on literature data, it is assumed that explants from 3- to 5-day-old seedlings gave the best regeneration results among various Brassica spp. (rev. Cardoza and Stewart 2004). Considering the young age of explants, it should be emphasized that their physiological and biochemical status is very active which means that the cell wall is not so rigid. As a consequence, it is more susceptible to the impact of environmental factors (e.g., exogenous 
PGRs). In fact, such young explants are too small for convenient manipulation. Probably that is why the majority of researchers use much older seedlings, 7- or even 10-day-old (Pavlovic et al. 2010; Ravanfar et al. 2014; Gerszberg et al. 2015; Gambhir et al. 2017a).

\section{Types of media and growth regulators}

The choice of an appropriate medium and the right dose of PGRs is another crucial factor for cabbage efficient regeneration. So far, many variants of substrate based on MS (Murashige and Skoog, 1962) or B5 (Gamborg et al. 1968) have been tested (Krzyżanowska et al. 2006; Rafat et al. 2010; Ravanfar et al. 2014; Gerszberg et al. 2015; Gambhir et al. 2017a). The addition of hormones to the substrate was not always necessary. For example, in the case of cabbage regeneration from androgenic embryos, B5 phytohormone free medium proved better in comparison to MS medium (Krzyżanowska et al. 2006). However, medium supplementation with exogenous PGRs has a significant impact on callus inductions, morphogenesis and rooting. A lot of publications indicated that addition of cytokinins alone or with auxins at low concentration significantly increased the efficiency of cabbage regeneration (Krzyżanowska et al. 2006; Pavlovic et al. 2013; Gambhir and Srivastava 2015; Gerszberg et al. 2015; Ertac and Tuncer 2016). At present, researchers have a range of exogenous PGRs to be used in plant in vitro culture. The literature data show that in in vitro cultures for cabbage regeneration, indole-3-acetic acid (IAA), indole-3-butyric acid (IBA), $\alpha$-naphthylacetic acid (NAA), 2,4-D (2,4-Dichlorophenoxy-acetic acid), 6-benzyloaminopurine (6-BAP), kinetin (Kin), thidiazuron (TDZ), 6-(gamma,gamma-dimethylallylamino)purine (2iP) are most commonly used (Chen et al. 2004; Sharma et al. 2014; Ravanfar et al. 2014; Gerszberg et al. 2015; Gambhir et al. 2017a). In protoplast culture, 2,4-Dichlorophenoxyacetic acid (2,4-D), picloram, and gibberellic acid $\left(\mathrm{GA}_{3}\right)$ were tested (Fu et al. 1985; Chen et al. 2004; Liu et al. 2007), while in microspore culture abscisic acid (ABA) was used (Rudolf et al. 1999). The modifications of the substrate conditions allowed for successful B. oleracea var. capitata shoot induction from various explants from different cultivars (Table 1).

Summing up the available results (Table 1), it can be concluded without any doubt that the best results of cabbage regeneration were obtained when MS medium fortified with cytokinins and a small amount of auxins was used. Furthermore, the research results suggested the superiority of one type of cytokinin (TDZ) over the others (BAP, 2iP, Kin etc.). Ravanfar et al. (2014) hypothesized that this resulted from the fact that TDZ was able to induce the synthesis of endogenous auxins. Although the induction of shoots from cotyledons is possible, majority of the studies proved that hypocotyls explant had higher morphogenic potential.

\section{Organogenesis}

To regenerate plantlets in vitro, two methods are exploited: organogenesis (direct and indirect) and embryogenesis (direct or indirect). Considering the goal (e.g., heredity or genetic transformation) of the study conducted, the first method is much more advisable because it allows evasion of genetic variations. Regarding cabbage, there are reports on its regeneration by direct (Gambhir and Srivastava 2015; Gambhir et al. 2017a) and indirect organogenesis (Munshi et al. 2007; Dănăilă-Guidea et al. 2012; Gerszberg et al. 2015; Ertac and Tuncer 2016) as well as by somatic embryogenesis pathway (Pavlovic et al. 2013). It should be emphasized that, although somatic embryogenesis is successfully exploited in a wide range of different species, it has been seldom notified in Brassicas. The literature data clearly indicate that the effectiveness of regeneration is significantly correlated with the genotype and the type of explant (Klima et al. 2004; Munshi et al. 2007; Krzyżanowska et al. 2006; Dănăilă-Guidea et al. 2012; Gerszberg et al. 2015). It turned out that there were cultivars recalcitrant to regeneration under the applied conditions (Dănăilă-Guidea et al. 2012; Gerszberg et al. 2015). Additionally, it was noticed that the quantity of callus produced from explants did not positively correlate with the subsequent shoot induction. Moreover, the cotyledon explants produced much smaller callus amount and this process was slower in comparison to the hypocotyl explants (Gerszberg et al. 2015).

Rooting is the last step of plant regeneration in vitro. It depends on many factors including the medium composition, PGRs types and concentrations, as well as the physiological status of plantlets. Different variants of MS or $1 / 2 \mathrm{MS}$ medium with or without various types and concentrations of auxin (e.g., IBA, IAA, NAA or 2,4-D), were successfully used to induce cabbage rooting process (Munshi et al. 2007; Sharma et al. 2014; Ravanfar et al. 2014; Qamar et al. 2014; Ertac and Tuncer 2016; Gambhir et al. 2017a). According to some researchers, the best rooting results are obtained using PGR-free medium (Ravanfar et al. 2014). On the other hand, others achieved better results when using MS supplemented with small concentrations of auxins (ranging from 0.1 to $0.5 \mathrm{mg} / \mathrm{L}$ ) (Munshi et al. 2007; Sharma et al. 2014; Gerszberg et al. 2015; Gambhir et al. 2017a). Thus, additives, even at small concentrations, significantly intensified the process of rooting, while their higher concentrations affected root morphologies (Pavlovic et al. 2010; Gerszberg et al. 2015). Furthermore, Sharma et al. (2014) pointed out that the rooting process depended on the type of auxin, its concentration as well as the plantlet from which the explant came from. Munshi et al. (2007), similar to Sharma et al. (2014), 
achieved the best rooting results exploiting IBA. Certainly, 2,4-D proved to be the least effective in rooting, which caused the formation of callus at the base of the regenerated plantlets (Munshi et al. 2007). Similar effects were obtained in the case of elevated NAA $(5.2-8.0 \mu \mathrm{M})$ concentrations (Gerszberg et al. 2015). Pavlovic et al.'s (2010) research indicated that in the case of cabbage, the type of auxin and its concentration in the rooting medium sugar concentration are also important.

\section{Possible problems during in vitro cultures}

During in vitro regeneration of different plant species including cabbage, various problems may arise, including vitrification of plant tissue or chlorosis and necrosis along with prolonged growing period on a given substrate. Vitrification involves excessive hydration of tissues ("glassy" appearance), caused by high levels of moisture in the jar, growth regulators (e.g., BAP) in the nutrient medium as well as limited exposure to light (Pavlovic et al. 2012; Ravanfar et al. 2014). Such plants were characterized with deformed chloroplasts, moreover, they were found to have problems with the synthesis of chlorophyll and other dyes as well as enzymatic activity. As a result, they are not able to live under greenhouse conditions. This problem can be solved with increasing the concentration of the nutrient medium (e.g., agar), thus limiting the availability of water. Chlorosis and then necrosis may be the result of accumulation of ethylene in the jars or Petri dishes due to reduced gas exchange. Another possible explanation of the aforementioned phenomena may be the leakage of phenolic compounds, oxidation of which yields toxic compounds to the substrate. This phenomenon often occurs in in vitro cultures of plants rich in phenolic compounds, and cabbage is such a plant (Gerszberg et al. 2015). Since it is known that silver nitrate (AgNO3) strongly inhibits ethylene action, it can be added to the medium at a low concentration to overcome this obstacle (Cristea et al. 2012).

\section{Hardening}

Subsequently, fully regenerated plants should be hardened. Typically, cabbage plants are placed in the substrate, which is a mixture of soil and compost (2:1) (Munshi et al. 2007), coconut and vermicompost (7:3) (Ravanfar et al. 2014), soil and perlite (3:1) (Gerszberg et al. 2015) or coco peat (Gambhir et al. 2017a). According to the literature data, the survival rate of regenerated plants after hardening varies from 70 to 95\% (Sharma et al. 2014; Daud et al. 2015; Gerszberg et al. 2015). Pavlovic et al. (2010) indicated an interesting correlation between the concentration of sugar in the rooting substrate and the survival of the regenerated plants during acclimation, namely, the higher sugar concentration, and the higher survival of plants.

\section{Genetic transformation of Brassica oleracea var. capitata via Agrobacterium}

Agrobacterium-mediated transformation is widely employed to transfer a gene of interest (GOI) to crop species important from the economic point of view. However, most of them are recalcitrant to genetic modifications, since a lot of protocols are developed for model plants. Therefore, based on existing protocols, they should be properly refined for individual commercial plant species including cabbage.

A review of the literature indicates the use of both $A$. rhizogenes and A. tumefaciens for the transformation of cabbage. The former pathway is rarely used for cabbage transformation. Considering A. rhizogenes-mediated transformation, it should be noted that transgenic roots of cabbage were successfully obtained, whereas difficulties appeared at the stage of plant regeneration. The results pointed out that shoot regeneration from hairy roots was genotype dependent and some genotypes were even recalcitrant to the applied regeneration condition (Stretnovic-Rajicic et al. 2006). Moreover, the phenotype of some hairy root-derived plantlets was abnormal which was manifested by reduced apical dominance, wrinkled leaves, short internodes and male sterility (poor pollen production) (Berthomieu and Jouanin 1992; Bhala and Singh 2008). On the other hand, some of the obtained plants were normal in terms of phenotype and even better developed than the control plants (Stretnovic-Rajicic et al. 2006). It can be concluded that due to the described difficulties, A. rhizogenes-mediated transformation method is rarely used to transform cabbage. This is also confirmed by scanty publication data concerning this issue. A. tumefaciens-mediated transformation is used more often (Yi et al. 2013; Hur and Min 2015). However, also in this case the transformation efficiency is not satisfactory (Liu et al. 2008). Nevertheless, attempts are made to optimize individual transformation parameters (Bhala and Singh 2008; Rafat et al. 2010). Moreover, to reduce public concerns over the exploit of genes giving antibiotic resistance, some research groups tried to establish an alternative, safer selection system (Hur and Min 2015). An effective genetic transformation of cabbage is strictly genotypically dependent; furthermore, some varieties are recalcitrant to transformation. So, it is clear that it is not possible to develop a universal cabbage transformation protocol. Therefore, it seems fully logical to establish a reliable transformation and regeneration procedure for specific cultivars. This trend in studies conducted in many laboratories is observed (Table 2). Most studies are dedicated to introducing genes conferring tolerance to insect or abiotic stresses. Based on 
the available literature in this topic, the current article proposes an outline of the general procedure for cabbage transformation via Agrobacterium (Fig. 2). It may be a starting point for modification and developing a protocol dedicated to a specific variety.

\section{Crucial factors for successful Agrobacterium-mediated cabbage transformation}

Successful genetic transformation via A. tumefaciens depends on susceptibility of cabbage infections and GOI incorporation to the genome as well as ability to regenerate plants from transformed cells in in vitro culture. The results from the last three decades allowed to identify factors which played a pivotal role in the successful transformation of cabbage.

\section{Explant type and explant age}

Different cabbage explants were used for transformation; however, hypocotyl and shoot tip derived ones offered the best transformation efficiency (Rafat et al. 2010). Young explants, i.e., 4- to 9-day-old seedlings were mainly used for transformation ( $\mathrm{Li}$ et al. 2005; Rafat et al. 2010; Yi et al. 2013). As mentioned previously, such explants were characterized with better morphogenic response and had more flexible cell wall which made them more susceptible to PGRs and Agrobacterium impact. Consequently, it is recommended to place explants on a pre-culture medium with PGR as an osmotic practice (Yi et al. 2013; Hur and Min 2015). Interestingly, not every type of cabbage explant requires such treatment. The pre-culture treatment is indispensable in the case of hypocotyl or cotyledon explants hypersensitive to Agrobacterium, while it is not necessary for shoot tip explants as the studies of Rafat et al. (2010) and Hur and Min (2015) revealed.

\section{Agrobacterium strain, concentration, inoculation and co-cultivation period}

Summarizing the examples of successful cabbage transformation (Table 2), it was noticed that Agrobacterium LBA 4404 octopine strain was commonly used. It is known that virulence of a strain is important for successful transformation and the aforementioned strain is of moderate virulence. Agrobacterium concentration $\left(\mathrm{OD}_{600}\right)$ was one of the most crucial factors for plant infection. According to the available data, Agrobacterium at the concentrations 0.4-0.5 or 1.6-1.8 was used for B. oleracea var. capitata transformation (Metz et al. 1995; Li et al. 2005; Rafat et al. 2010; Yi et al. 2013). Based on the results it can be stated that, to avoid explants necrosis or even death, Agrobacterium OD at $\chi=600 \mathrm{~nm}$ should be adjusted to
0.05-0.1, the inoculation time should not exceed $10 \mathrm{~min}$ and co-cultivation time-3 days (Yi et al. 2013). Furthermore, supplementation of the bacterial growth medium or the co-cultivation medium with phenolic compounds was reported to significantly improve transformation efficiency regardless of the Agrobacterium strain used (Bhattacharya et al. 2002; Rafat et al. 2010).

\section{Antibiotics}

One of the indispensable factors during the genetic transformation of plants is the use of specific antibiotics (e.g., selective or bactericidal ones). Their concentration should be optimized before transformation to determine an effective dose leading to plants regeneration as well as a lethal dose for Agrobacterium. This step is extremely important due to the fact that the prolonged presence of Agrobacterium in plant tissues affects the growth and development of explants and can even cause necrosis and consequently their death (Stanišić et al. 2018). Furthermore, presence of Agrobacterium in tissue of putative transformants could result in false positive results in the molecular analyses. In addition, elimination of Agrobacterium from transformed plants prevents the possibility of accidental release of transgenes to the environment when transformants are transferred to the soil (Tambarussi et al. 2015). Beta-lactam antibiotics (e.g., carbenicillin, cefotaxime and timentin) are most commonly used for combating Agrobacteria after genetic transformation (Stanišić et al. 2018). Due to the difficulty in the transformation of cabbage, only few papers related to this subject were published. However, in the articles concerning Agrobacterium-mediated transformation of cabbage, mainly cefotaxime or carbenicillin (as a bacterial eliminating factor) at $500 \mathrm{mg} / \mathrm{L}$ concentration was used along with kanamycin ( $25 \mathrm{mg} / \mathrm{L}$ ) (a selection factor) (Paul et al. 2005; Rafat et al. 2010; Yi et al. 2011).

According to the author's knowledge, only few publications exist on the optimization of antibiotic concentrations after the genetic transformation of cabbage. In the last decade, only two publications strictly related to this topic appeared. Rafat et al. (2010) in his research tested different variants of hygromycin as a selection factor; however, he did not provide results from this part of the experiment. The only conclusion about hygromycin was that it definitely had a stressful effect on transformed plants. Whereas Gambhir et al. (2017b) focused on the effect of cefotaxime and kanamycin in a wide range of concentrations on transformed cabbage tissues. Their results revealed a negative correlation between the concentration of kanamycin $(0-60 \mathrm{mg} / \mathrm{L})$ and fresh weight of the explants (leaf and petiole), while cefotaxime at different concentrations $(0-500 \mathrm{mg} / \mathrm{L})$ did not have much effect on cabbage regeneration potential. 
Table 2 Genetic improvements of Brassica oleracea var. capitata

\begin{tabular}{|c|c|c|c|c|c|}
\hline $\begin{array}{l}\text { B. oleracea var. capi- } \\
\text { tata cultivar }\end{array}$ & $\begin{array}{l}\text { Technique of gene } \\
\text { transfer }\end{array}$ & Gene transfer & Improvement in traits & Type of explant used & References \\
\hline 161 & $\begin{array}{l}\text { A. rhizogenes }\left(\mathrm{A}_{4} \mathrm{~K} \text {, }\right. \\
\left.\quad \mathrm{A}_{4} \mathrm{H}\right)\end{array}$ & nptII, hph & $\begin{array}{l}\text { Resistance to kanamy- } \\
\text { cin, hygromycin }\end{array}$ & $\begin{array}{l}\text { Leaf petioles, inter- } \\
\text { nodes }\end{array}$ & $\begin{array}{l}\text { Berthomieu and Jouanin } \\
\text { (1992) }\end{array}$ \\
\hline King Cole & A. tumefaciens (AB1) & cryla $(c)$ & $\begin{array}{l}\text { Resistance to diamond } \\
\text { back moth (P.xylos- } \\
\text { tella) }\end{array}$ & $\begin{array}{l}\text { Hypocotyls, coty- } \\
\text { ledons, petioles, } \\
\text { peduncle from } \\
\text { flowering stalks }\end{array}$ & Metz et al. (1995) \\
\hline Yingchun, Jingfeng & $\begin{array}{l}\text { A. tumefaciens } \\
\text { (LBA4404) }\end{array}$ & $C p T I$ & $\begin{array}{l}\text { Insect tolerance to } \\
\text { Pieris rapae L. }\end{array}$ & N/A & Hongjun et al. (1997) \\
\hline $\begin{array}{l}\text { Hercules, Brunswick, } \\
\text { Cape spitz, Copen- } \\
\text { hagen }\end{array}$ & $\begin{array}{l}\text { A. tumefaciens } \\
\text { (LBA4404) }\end{array}$ & nptII & $\begin{array}{l}\text { Resistance to kana- } \\
\text { mycin }\end{array}$ & Cotyledons & Pius and Achar (2000) \\
\hline Scorpio, Testie & $\begin{array}{l}\text { A. tumefaciens } \\
\text { (EHA105) }\end{array}$ & crylla3 & $\begin{array}{l}\text { Resistance to diamond } \\
\text { back moth (P.xylos- } \\
\text { tella) }\end{array}$ & $\begin{array}{l}\text { Hypocotyls, cotyle- } \\
\text { dons, petioles }\end{array}$ & Jin et al. (2000) \\
\hline Uji & $\begin{array}{l}\text { A. tumefaciens } \\
\text { (LBA4404) }\end{array}$ & $G O$ & $\begin{array}{l}\text { Enhanced tolerance to } \\
\text { black rot disease by } \\
\text { Xanthomonas camp- } \\
\text { estris pv. campestris }\end{array}$ & Hypocotyls & Lee et al. (2002) \\
\hline $\begin{array}{l}\text { B. oleracea var. capi- } \\
\text { tata } \mathrm{cv} \text {. N/A }\end{array}$ & $\begin{array}{l}\text { A. tumefaciens } \\
\text { (LBA4404) }\end{array}$ & $B c A 9$ & $\begin{array}{l}\text { Induction of male } \\
\text { sterile cabbage }\end{array}$ & Hypocotyls & Lee et al. (2003) \\
\hline Golden Acre & $\begin{array}{l}\text { A. tumefaciens } \\
\text { (GV2260) }\end{array}$ & bet A & $\begin{array}{l}\text { Enhanced salt toler- } \\
\text { ance }\end{array}$ & Hypocotyls & $\begin{array}{l}\text { Bhattacharya et al. } \\
\text { (2004) }\end{array}$ \\
\hline DTC 507 & A. tumefaciens (N/A) & cryl b & $\begin{array}{l}\text { Resistance to diamond } \\
\text { back moth }(P . x y l o s- \\
\text { tella })\end{array}$ & $\begin{array}{l}\text { Hypocotyls, cotyle- } \\
\text { donary nodes }\end{array}$ & Paul et al. (2005) \\
\hline Xiaguang & $\begin{array}{l}\text { A. tumefaciens } \\
\text { (LBA4404) }\end{array}$ & $v h b$ & $\begin{array}{l}\text { Increases submergence } \\
\text { tolerance }\end{array}$ & $\begin{array}{l}\text { Hypocotyls, cotyle- } \\
\text { dons, petioles }\end{array}$ & Li et al. (2005) \\
\hline N/A & $\begin{array}{l}\text { A. tumefaciens } \\
\text { (LBA4404) }\end{array}$ & $O C-I$ & Insect resistance & $\begin{array}{l}\text { Hypocotyls, cotyle- } \\
\text { dons }\end{array}$ & Lei et al. (2006) \\
\hline P34I5, P22I5 & $\begin{array}{l}\text { A. rhizogenes } \\
\text { (A4M70GUS) }\end{array}$ & gus & N/A & $\begin{array}{l}\text { Hypocotyls, cotyle- } \\
\text { dons }\end{array}$ & $\begin{array}{l}\text { Stretnović-Rajičić et al. } \\
\text { (2006) }\end{array}$ \\
\hline $\begin{array}{l}\text { Summer Summit, KY } \\
\text { cross }\end{array}$ & Biolistic method & gus & N/A & Chloroplasts & Liu et al. (2007) \\
\hline $\begin{array}{l}\text { Summer Summit, KY } \\
\text { cross }\end{array}$ & Biolistic method & $\operatorname{cry} 1 A b$ & $\begin{array}{l}\text { Resistance to diamond } \\
\text { back moth (P.xylos- } \\
\text { tella) }\end{array}$ & Chloroplasts & Liu et al. (2008) \\
\hline KY Cross & $\begin{array}{l}\text { A. tumefaciens } \\
\text { (GV2260) }\end{array}$ & AtHSP101 & $\begin{array}{l}\text { Increase the high tem- } \\
\text { perature tolerance }\end{array}$ & $\begin{array}{l}\text { Hypocotyls, shoot tip } \\
\text { segments }\end{array}$ & Rafat et al. (2010) \\
\hline CA21-3 & $\begin{array}{l}\text { A. tumefaciens } \\
\text { (EHA105) }\end{array}$ & crylBa3 & $\begin{array}{l}\text { Resistance to diamond } \\
\text { back moth (P.xylos- } \\
\text { tella) }\end{array}$ & $\begin{array}{l}\text { Hypocotyls, cotyle- } \\
\text { dons }\end{array}$ & Deng-xia et al. (2011) \\
\hline A21-3' & $\begin{array}{l}\text { A. tumefaciens } \\
\text { (LBA4404) }\end{array}$ & cry $11 a 8$, cry 1 Ba 3 & $\begin{array}{l}\text { Resistance to diamond } \\
\text { back moth (P.xylos- } \\
\text { tella) }\end{array}$ & Hypocotyls & Yi et al. (2013) \\
\hline N/A & Biolistic method & & N/A & Chloroplasts & Tseng et al. (2014) \\
\hline AD BENTAM & $\begin{array}{l}\text { A. tumefaciens } \\
\text { (LBA4404) }\end{array}$ & $P M I, J M T$ & $\begin{array}{l}\mathrm{PMI} / \text { mannose selec- } \\
\text { tion system; resist- } \\
\text { ance to stress }\end{array}$ & $\begin{array}{l}\text { Hypocotyls, cotyle- } \\
\text { dons }\end{array}$ & Hur and Min (2015) \\
\hline Pride of India & A. tumefaciens (N/A) & cry IAa & $\begin{array}{l}\text { Study of the effect of } \\
\text { antibiotic sensitivity } \\
\text { on cabbage tissue }\end{array}$ & $\begin{array}{l}\text { Hypocotyls, cotyle- } \\
\text { dons }\end{array}$ & Gambhir et al. (2017b) \\
\hline
\end{tabular}

N/A not available 
Excision of explant (e.g. hypocotyls, cotyledons) from young (4-9-day-old) seedling

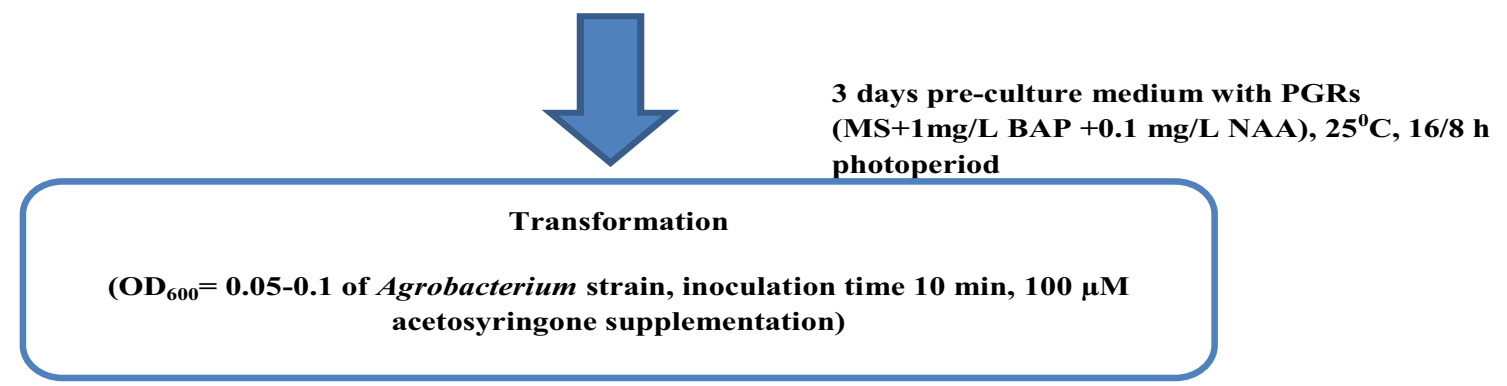

3 days co-cultivation time in dark; $25^{\circ} \mathrm{C}$

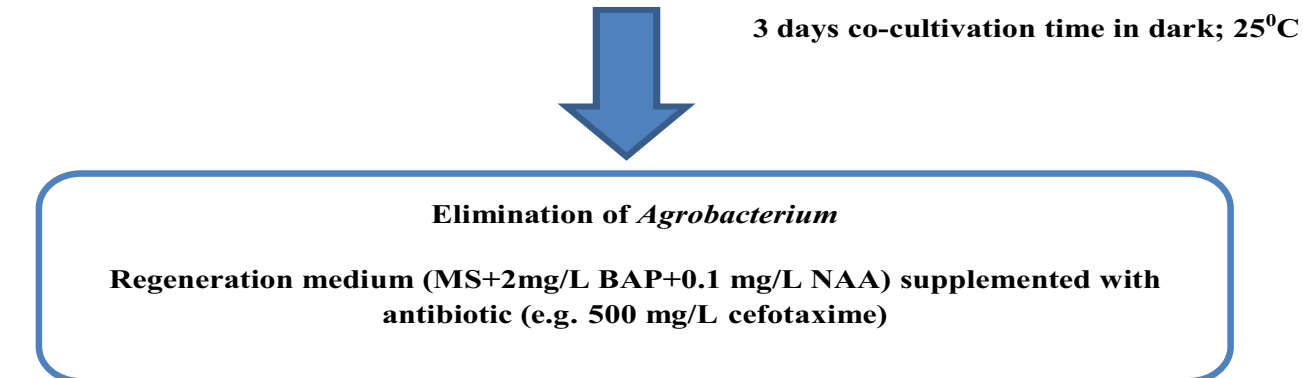

7 days, $25^{\circ} \mathrm{C}, 16 / 8$ h photoperiod

Selection of transformed cells on regeneration medium ((MS+2mg/L BAP+0.1 mg/L NAA) supplemented with antibiotics (e.g. 20-25 mg/L hygromycin or kanamycin and $500 \mathrm{mg} / \mathrm{L}$ cefotaxime)

Green shoots move on to rooting medium (MS PGR free or MS+0.1 mg/L NAA or IBA + 20-25 mg/L hygromycin or kanamycin and $500 \mathrm{mg} / \mathrm{L}$ cefotaxime)

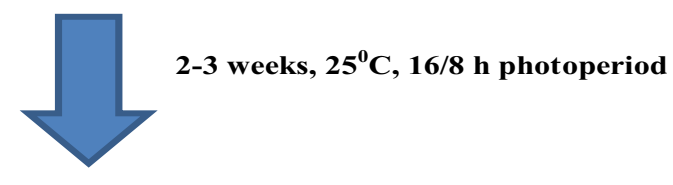

\section{Hardening}

Transfer rooted plantlets to soil (mixture of soli and perlite (3:1))

Fig. 2 Outline of procedure for Agrobacterium-mediated transformation of cabbage 


\section{Particle bombardment of cabbage}

Since the first stable chloroplast genetic transformation in higher plants was proved, it has been successfully exploited to transform a wide range of different species of plants (Hnatuszko-Konka et al. 2014; Bock 2015; Gerszberg and Hnatuszko-Konka 2017). Generally, it is known that there is a high level of foreign gene expression in plastids, thus the protein level of these transgenes is high. Therefore, this transformation method can be another way to obtain transgenic cabbage with quite new agronomic or horticultural traits. The first protocol for stable chloroplast transformation in B. oleracea var. capitata by particle bombardment was established by Liu et al. (2007). Based on this procedure, a year later Liu et al. (2008) obtained transgenic cabbage with expression of crylA $b$ gene in chloroplasts. However, the transformation frequency for the same cultivars (K-Y and Summer Summit) was lower than in the previous study (Liu et al. 2007). It might have resulted from the fact that fully expanded leaves were used as explants. Although older leaves have mature chloroplasts, it is more difficult to obtain transgenic plants (transplastomic lines) from them. Liu et al. (2008) pointed out that successful foreign gene integration with chloroplast genome of cabbage required flanking sequence homology in the applied vector to the chloroplast genome. Extremely low homology (less than 100\%) is the cause of low transformation frequency (Tseng et al. 2014).

\section{Conclusions}

B. oleracea var. capitata as a crop plant is of great economic importance all over the world. Unfortunately, its yields are depleted by various environmental stresses (abiotic and biotic). However, great advance in the field of plant tissue culture, molecular biology as well as genetic engineering has offered new solutions for genetic improvement of significant vegetable crops including cabbage. This review provides an insight into different regeneration and transformation studies in cabbage. Based on the literature data, it can be concluded that B. oleracea var. capitata appears recalcitrant to genetic engineering. Moreover, its successful regeneration and transformation procedure strongly depends on the genotype. A lot of factors were proved essential for increasing shoot regeneration and for enhancing transformation frequency. To obtain the best effects, it is necessary to establish optimized procedures mentioned above, even for particular important varieties. If this condition is met, it will be possible to commercialize cabbage plants with new desirable traits. Therefore, according to the author's conviction, the proposed review of the available data could be a useful starting point for the development of efficient transformation/regeneration protocols for specific cultivars.

Author contribution statement AG conceived the idea of the review and prepared the initial outline, tables, figures as well as wrote the manuscript.

Acknowledgments This work was supported by University of Lodz (research fund B 1711000000201.01).

\section{Compliance with ethical standards}

Conflict of interest The author declares that the research was conducted in the absence of any commercial or financial relationships that could be construed as a potential conflict of interest.

Open Access This article is distributed under the terms of the Creative Commons Attribution 4.0 International License (http://creativeco mmons.org/licenses/by/4.0/), which permits unrestricted use, distribution, and reproduction in any medium, provided you give appropriate credit to the original author(s) and the source, provide a link to the Creative Commons license, and indicate if changes were made.

\section{References}

Berthomieu P, Jouanin L (1992) Transformation of rapid cycling cabbage (Brassica oleracea var.capitata) with Agrobacterium rhizogenes. Plant Cell Rep 11:334-338

Bhala PL, Singh MB (2008) Agrobacterium mediated transformation of Brassica napus and Brassica oleracea. Nat Protoc 3:181-189

Bhattacharya RC, Viswakarma N, Bhat SR, Kirti PB, Chopra VL (2002) Development of insect-resistant cabbage plants expressing a synthetic crylAb gene from Bacillus thuringiensis. Curr Sci 83:146-150

Bhattacharya RC, Maheswari M, Dineshkumar V, Kirti PB, Bhat SR, Chopra VL (2004) Transformation of Brassica oleracea var. capitata with bacterial betA gene enhances tolerance to salt stress. Sci Hortic 100:215-227

Bock R (2015) Engineering plastid genomes: methods, tools, and applications in basic research and biotechnology. Annu Rev Plant Biol 66:211-241. https://doi.org/10.1146/annurev-arplant-05021 3-040212

Cardoza V, Stewart NC (2004) Brassica biotechnology: progress in cellular and molecular biology. In Vitro Cell Dev Biol Plant 40:542-551

Chen LP, Zhang MF, Xiao QB, Wu JG, Hirata Y (2004) Plant regeneration from hypocotyl protoplasts of red cabbage (Brassica oleracea) by using nurse cultures. Plant Cell Tiss Org Cult 77:133-138

Cristea TO, Leonte C, Brezeanu C, Brezeanu M, Ambarus S, Calin M, Prisecaru M (2012) Effect of $\mathrm{AgNO}_{3}$ on androgenesis of Brassica oleracea L. anthers cultivated in vitro. Afr J Biotechnol 11(73):13788-13795

Dănăilă-Guidea S, Rosu A, Ionica M, Visan L, Dobrinoiu R (2012) Caulogenesis approaches applied in vitro micropropagation varieties-Cabeza Negra 2, Arena and Red Amager - of Brassica oleracea var. capitata rubra form. Curr Trend Nat Sci 1(1):075-079 
Daud NFA, Hasbullah NA, Azis NA, Rasad FM, Amin MAM, Lassim MM (2015) In vitro regeneration of Brassica oleracea var. capitata trough steams, roots, leaves and petioles cultures. International Conference on Agricultural, Ecological and Medical Sciences (AEMS-2015) April 7-8, 2015 Phuket (Thailand). http:// dx.doi.org/10.15242/IICBE.C0415004

Ertac F, Tuncer B (2016) In vitro shoot and root regeneration in Ercis cabbage (Brassica oleracea var. capitata). VII International Scientific Agriculture Symposium, "Agrosym 2016", 6-9 October 2016, Jahorina, Bosnia and Herzegovina. Proceedings 2016 pp $170-175$ ref.14

FAOSTAT 2016, http://www.fao.org

Fu Y, Jia S, Lin Y (1985) Plant regeneration from mesophyll protoplasts culture of cabbage (Brassica oleracea L. var. capitata). Theor Appl Genet 71:495-499

Gambhir G, Srivastava DK (2015) Thidiazuron induces high frequency shoot regeneration in leaf and petiole explants of cabbage (Brassica oleracea $L$. var. capitata). J Biotechnol Biomater 5:172. https ://doi.org/10.4172/2155-952x.1000172

Gambhir G, Kumar P, Srivastava DK (2017a) High frequency regeneration of plants from cotyledon and hypocotyl cultures in Brassica oleracea cv. Pride of India. Biotechnol Rep 15(2017):107-113. https://doi.org/10.1016/j.btre.2017.02.005

Gambhir G, Kumar P, Srivastava DK (2017b) Effect of antibiotic sensitivity on different cultured tissues and its significance in genetic transformation of cabbage Brassica oleracea. Biosci Biotech Res Commun 10(4):652-661

Gamborg OL, Miller RA, Ojima O (1968) Nutrient requirements of suspension cultures of soybean root cell. Exp Cell Res 50:151-158

Gerszberg A, Hnatuszko-Konka K (2017) Tomato tolerance to abiotic stress: a review of most often engineered target sequences. Plant Growth Regul 83:175. https://doi.org/10.1007/s10725-017-0251-x

Gerszberg A, Hnatuszko-Konka K, Kowalczyk T (2015) In vitro regeneration of eight cultivars of Brassica oleracea var. capitata. In Vitro Cell Dev Biol Plant 51:80-87. https://doi.org/10.1007/ s11240-014-0664-4

Hafidh RR, Abdulamir AS, Bakar FA, Jalilian FA, Jahanshiri F, Abas F, Sekawi Z (2013) Novel anticancer activity and anticancer mechanisms of Brassica oleracea L. var. capitata f. rubra. Eur J Integr Med 5:450-464

Hnatuszko-Konka K, Kowalczyk T, Gerszberg A, Wiktorek-Smagur A, Kononowicz AKK (2014) Phaseolus vulgaris-recalcitrant potential. Biotechnol Adv 32:1205-1215. https://doi.org/10.1016/j.biote chadv.2014.06.001

Hongjun F, Dali L, Guanlin W, Yinghui L, Zhen Z, Xianghui L (1997) An insect-resistant transgenic cabbage plant with cowpea trypsin inhibitor (CPTI) gene. Acta Bot Sinica 39(10):940-945

Hur SH, Min BW (2015) Efficient development of transgenic Cabbage with jasmonic acid carboxyl methyltransferase (JMT) gene based on PMI/mannose selection system. Plant Breed Biotech 3(3):226237. https://doi.org/10.9787/PBB.2015.3.3.226

Jin RG, Liu YB, Tabashnik BE, Borothakur D (2000) Development of transgenic cabbage (Brasica oleracea var.capitata) for insect resistance by Agrobacterium tumefaciens- mediated transformation. In Vitro Cell Dev Biol Plant 36:231-237

Kiełkowska A, Damaus A (2012) An alginate-layer technique for culture of Brassica oleracea L. protoplasts. In Vitro Cell Dev Biol Plant 48:265-273

Klima M, Vyvadilová M, Kučera V (2004) Production and utilization of doubled haploids in Brassica oleracea vegetables. Hort Sci (PRAGUE) 31(4):119-123

Krzyżanowska D, Górecka K, Kiszczak W, Kowalska U (2006) The effect of genotype and medium on plant regeneration from androgenic embryos. J Fruit Ornam Plant Res 14(Supp. 1):121
Lee YH, Yoon IS, Suh SC (2002) Kim HI (2002) Enhanced disease resistance in transgenic cabbage and tobacco expressing a glucose oxidase gene from Aspergillus niger. Plant Cell Rep 20:857-863

Lee YH, Chung KH, Kim HU, Jin YM, Kim HI, Park BS (2003) Induction of male sterile cabbage using a tapetum-specific promoter from Brassica campestris L. ssp. pekinensis. Plant Cell Rep 22:268-273. https://doi.org/10.1007/s00299-003-0688-4

Lei JJ, Yang WJ, Yuan SH, Ying FY, Qiong LC (2006) Study on transformation of cysteine proteinase inhibitor gene into cabbage ( $\mathrm{Bra}$ sica oleracea var. capitata L.). Acta Hortic 706:231-238. https:// doi.org/10.17660/ActaHortic.2006.706.27

Li X, Peng RH, Fan HQ, Xiong AS, Yao QH, Cheng ZM, Li Y (2005) Vitreoscilla hemoglobin overexpression increases submergence tolerance in cabbage. Plant Cell Rep 23:710-715. https://doi. org/10.1007/s00299-004-0872-1

Liu CW, Lin CC, Chen JJW, Tseng MJ (2007) Stable chloroplast transformation in cabbage (Brassica oleracea L. var. capitata L.) by particle bombardment. Plant Cell Rep 26:1733-1744

Liu CW, Lin CC, Yiu JC, Chen JJW, Tseng MJ (2008) Expression of a Bacillus thuringiensis toxin (crylAb) gene in cabbage (Brassica oleracea L. var. capitata L.) chloroplasts confers high insecticidal efficacy against Plutella xylostella. Theor Appl Genet 17:75-88. https://doi.org/10.1007/s00122-008-0754-y

Liu S, Liu Y, Yang X, Tong C, Edwards D, Parkin IAP et al (2014) The Brassica oleracea genome reveals the asymmetrical evolution of polyploid genomes. Nat Commun 5:3930. https://doi. org/10.1038/ncomms4930

Metz DT, Dixit R, Earle DE (1995) Agrobacterium tumefaciensmediated transformation of broccoli (Brassica oleracea var. italica) and cabbage (B. oleracea var. capitata). Plant Cell Rep 15:287-292

Munshi MK, Roy PK, Kabir MH, Ahmed G (2007) In vitro regeneration of cabbage (Brassica oleracea L.var. capitata) through hypocotyl and cotyledon culture. Plant Tissue Cult Biotechnol 17(2):131-136

Murashige T, Skoog F (1962) A revised medium for rapid growth and bioassays with tobacco tissue cultures. Physiol Plant $15: 473-497$

Paul A, Sharma SR, Sresty TVS, Devi S, Bala S, Kumar PS, Saradhi PP, Frutos R, Altosaar I, Kumar PA (2005) Transgenic cabbage (Brassica oleracea var. capitata) resistant to Diamondback moth (Plutella xylostella). Indian J Biotechnol 4:72-77

Pavlovic S, Vinterhalter B, Mitic N, Adžić S, Pavlovic N, Zdravkovic $\mathrm{M}$, Vinterhalter D (2010) In vitro shoot regeneration from seedling explants in Brassica vegetables: red cabbage, broccoli, savoy cabbage and cauliflower. Arch Biol Sci 62:337-345

Pavlovic S, Adžic S, Cvikic D, Zdravkovic J, Zdravkovic M (2012) In vitro culture as a part of Brassica oleracea var. capitata $L$. breeding. Genetika 44(3):611-618

Pavlovic S, Vinterhalter B, Zdravkovic-Korac S, Vinterhalter D, Zdravkovic J, Cvikić D, Miti N (2013) Recurrent somatic embryogenesis and plant regeneration from immature zygotic embryos of cabbage (Brassica oleracea var. capitata) and cauliflower (Brassica oleracea var. botrytis). Plant Cell Tiss Organ Cult 113:397406. https://doi.org/10.1007/s11240-012-0279-6

Pius PK, Achar PN (2000) Agrobacterium-mediated transformation and plant regeneration of Brassica oleracea var. capitata. Plant Cell Rep 19:888-892

Qamar Z, Nasir IA, Jahangir GZ, Husnain T (2014) In vitro production of cabbage and cauliflower. Adv Life Sci 1(2):112-118

Rafat A, Aziz MA, Rashid AA, Abdullah SNA, Kamaladini H, Sirchi MHT, Javadi MB (2010) Optimization of Agrobacterium tumefaciens-mediated transformation and shoot regeneration after cocultivation of cabbage (Brassica oleracea subsp. capitata) cv.KY Cross with AtHSP101 gene. Sci Hortic 124:1-8 
Ravanfar SA, Salim S, Aziz MA, Abdullah SNA, Rashid AA (2014) Influence of phenyl-urea and adenine-type cytokinins on direct adventitious shoot regeneration of cabbage (Brassica oleracea subsp. capitata) "KCross". Biotechnology 31:1-6. https://doi. org/10.5511/plantbiotechnology.14.0514a

Ravanfar SA, Orbovic V, Moradpourd M, Azizd MA, Karana R, Wallace S, Parajuli S (2017) Improvement of tissue culture, genetic transformation, and applications of biotechnology to Brassica. Biotechnol Genet Eng Rev 33(1):1-25. https://doi. org/10.1080/02648725.2017.1309821

Rudolf K, Bohanec RK, Hansen M (1999) Microspore culture of white cabbage, Brassica oleracea var. capitata L.: genetic improvement of non-responsive cultivars and effect of genome doubling agents. Plant Breed 118:237-241

Sharma S, Gambhir G, Srivastava DK (2014) High frequency organogenesis in cotyledon and hypocotyl explants of cabbage (Brassica oleracea L var. capitata). Natl Acad Sci Lett 37(1):5-12. https:// doi.org/10.1007/s40009-013-0191-6

Stanišić M, Ninković S, Savić J, Ćosić T, Mitić N (2018) The effects of $\beta$-lactam antibiotics and hygromycin $\mathrm{B}$ on de novo shoot organogenesis in apple cv. Golden Delicious. Arch Biol Sci 70(1):179-190

Stretnović-Rajičić T, Ninkowić S, Miljuš-Dukić J, Vinterhalter B, Vinterhalter D (2006) Agrobacterium rhizogenes-mediated transformation of Brassica oleracea var. sabauda and B. oleracea var. capitata. Biol Plant 50(4):525-530

Tambarussi EV, Rogalski M, Nogueira FTS, Brondani GE, De Martin VF, Carrer H (2015) Influence of antibiotics on indirect organogenesis of teak. Ann For Res 58:177-183. https://doi. org/10.15287/afr.2015.345

Tseng MJ, Yang MT, Chu WR, Liu CW (2014) Plastid transformation in cabbage (Brassica oleracea $\mathrm{L}$. var. capitata $\mathrm{L}$.) by the biolistic process. In: Maliga P (ed) Chloroplast biotechnology. Methods in molecular biology (methods and protocols), vol 1132. Humana Press, Totowa

Yi D, Lei C, Li Y, Zhuang M, Zhang Y, Fang Z, Yang L (2011) Transformation of cabbage (Brassica oleracea $\mathrm{L}$. var. capitata) with $B t$ cry $1 \mathrm{Ba} 3$ gene for control of Diamondback Moth. Agric Sci China 10(11):1693-1700. https://doi.org/10.1016/s1671-2927(11)60167 $-3$

Yi D, Cui L, Wang L, Liu Y, Zhuang M, Zhang Y, Zhang J, Lang Z, Zhang Z, Fang Z, Yang L (2013) Pyramiding of Bt cryllas and cry $1 B a 3$ genes into cabbage (Brassica oleracea $\mathrm{L}$. var. capitata) confers effective control against diamondback moth. Plant Cell Tiss Organ Cult 115:419-428. https://doi.org/10.1007/s1124 0-013-0373-4

Zeng A, Yan J, Song L, Gao B, Li J (2015) Effects of ascorbic acid and embryogenic microspore selection on embryogenesis in white cabbage (Brassica oleracea L. var. capitata). J Hortic Sci Biotechnol 90(6):607-612

Zielińska M, Lewandowska U, Podsędek A, Cygankiewicz AI, Jacenik D, Sałaga M, Kordek R, Krajewska WM, Fichna J (2015) Orally available extract from Brassica oleracea var. capitata rubra attenuates experimental colitis in mouse models of inflammatory bowel diseases. J Func Foods 17:587-599. https://doi.org/10.1016/j. jff.2015.05.046 